\title{
Sociolinguistic Bibliography on "Code-Switching"
}

Consuelo Montes Granado

Universidad de Salamanca

Current bibliography concerning sociolinguistics is overwhelmingly extensive despite its relatively recent existence, dating from the early sixties. Due to its interdisciplinary scope, it includes sources from distinct scientifically-orientated research: the ethnography of communication, the sociology of language and social psychology, among others. Out of the vast bibliographical material which these three approaches provide, I have selected those studies focusing, individually or as part of a wider investigation, on the analysis, interpretation and potential prediction of a particular phenomenon: code-switching in intragroup or intergroup interaction.

Ammon, U., N. Dittmar, and K. J. Mattheier, eds. Sociolinguistics/Soziolinguistik: An International Handbook of the Science of Language and Society/Ein internationales Handbuck zur Wisssenschaft von Sprache und Gesellschaft. Berlin and New York: Walter de Gruyter, 1988.

Bell, R. T. Sociolinguistics Goals, Approaches and Problems. London: B. T. Batsford, 1976. Chs. 4 and 5.

Bernstein, B. "Social Class, Linguistic Codes and Grammatical Elements." Language and Speech 5 (1962): 221-40.

Bernstein, B. "Social Class, Language and Socialization." Language and Social Context. Ed. Pier Paolo Giglioli. Harmondsworth: Penguin, 1972. 157-78.

"A Sociolinguistic Approach to Socialization with some Reference to Educability." Directions in Sociolinguistics: The Ethnography of Communication. Ed. John Gumperz and Dell Hymes. Oxford: Basil Blackwell, 1986. 465-97.

Blom, J. P. and J. J. Gumperz. "Social Meaning in Linguistic Structures: Code-Switching in Norway." Directions in Sociolinguistics: The Ethnography of Communication. Ed. John Gumperz and Dell Hymes. Oxford: Basil Blackwell, 1986. 407-34.

Bouchard R. E. and H. Giles. "Prolegomena for Developing a Social Psychological Theory of Language." Attitudes towards Language Variation. Ed. Ellen Bouchard Ryan and Howard Giles. London: Edward Arnold, 1982. 208-23. 
1982.

, and H. Giles, eds. Attitudes towards Language Variation. London: Edward Arnold,

Breitborde, L. B. "Levels of Analysis in Sociolinguistic Explanation: Bilingual

Code-switching, Social Relations, and Domain Theory." International Journal of the

Sociology of Language 39 (1983): 5-43.

Cheshire, J. "Linguistic Variation and Social Function." Sociolinguistic Variation in

Speech Communities. Ed. Suzanne Romaine. London: Edward Arnold, 1982. 153-66.

Dittmar, N. Sociolinguistics. A Critical Survey of Theory and Application. Trans. Pieter

Peter Sand, A. M. Seuren and Kevin Whiteley. London: Edward Arnold, 1976. Secs.

$5.3,5.4$, and 5.5 .

Doise, W., A. Sinclair, and R. Y. Bourish. "Evaluation of Accent Convergence and

Divergence in Cooperative and Competitive Intergroup Situations." British Journal of

Social and Clinical Psychology 15 (1976): 247-52.

Dorian, N. C. Investigating Obsolescence: Studies in Language Contraction and Death.

Cambridge: Cambridge UP, 1989.

Downes, W. Language and Society. London: Fontana, 1984. Ch. 3.

Edwards, J. R. "Language Attitudes and Their Implications among English Speakers."

Attitudes towards Language Variation. Ed. Ellen Bouchard Ryan and Howard Giles.

London: Edward Arnold, 1982. 20-33.

Fasold, R. W. The Sociolinguistics of Society. Oxford: Basil Blackwell, 1984. Ch. 7.

Ferguson, Ch. "Diglossia” Word 15 (1959): 325-40. Rpt. Language and Social Context.

Ed. Pier Paolo Giglioli. Harmondsworth: Penguin, 1972. 232-51.

Fishman, J. A. "Bilingualism with and without Diglossia; Diglossia with and without Bilingualism.” Journal of Social Issues 23 (1967): 29-38.

. Sociolinguistics. A Brief Introduction. Rowley: Newbury House Publisher, 1971.

Sec. III.

- "The Relationship between Micro- and Macro- Sociolinguistics in the Study of

Who Speaks What Language to Whom and When." Sociolinguistics. Ed. J. B. Pride

and Janet Holmes. Harmondsworth: Penguin, 1972. 15-32.

. "The Sociology of Language." Language and Social Context. Ed. Pier Paolo

Giglioli. Harmondsworth: Penguin, 1972. 45-58.

"Domains and the Relationship between Micro- and Macro- Sociolinguistics."

Directions in Sociolinguistics: The Ethnography of Communication. Ed. John J.

Gumperz and Dell Hymes. Oxford: Basil Blackwell, 1986. 435-53.

Gal, S. "Variation and Change in Patterns of Speaking: Language Shifts in Austria."

Linguistic Variation: Modes and Methods. Ed. D. Sankoff. New York: New York Academic P, 1978. 227-38.

Language Shift: Social Determinants of Linguistic Change in Bilingual Austria.

New York: Academic P, 1979.

. "The Political Economy of Code Choice." Codeswitching: Anthropological and

Sociolinguistic Perspectives. Ed. Monica Heller. Berlin: Mouton/de Gruyter, 1988.

245-64.

Giglioli, P. P. ed. Language and Social Context. Harmondsworth: Penguin, 1972. 
Giles, H., and P. F. Powesland. Speech Style and Social Evaluation. European Monographs in Social Psychology, 7. London: Academic P, 1975.

and P. Smith. "Accommodation Theory: Optimal Levels and Covergence." Language and Social Psychology. Ed. Howard Giles and Robert St. Clair. Oxford: Basil Blackwell, 1979. 45-65.

D. M. Taylor, and R. Y. Bourish. "Towards a Theory of Interpersonal Accommodation through Language: Some Canadian Data." Language in Society 2 (1973): 177-92.

Greenfield, L. "Situational Measures of Normative Language Views in relation to Person, Place and Topic among Puerto Rico Bilinguals." Advances in the Sociology of Language. Ed. Joshua Fishman. Le Hague: Mouton, 1972. 2: 17-35.

Gumperz, J. J. "Conversational Code-Switching." Discourse Analysis. Ed. John J. Gumperz. Cambridge: Cambridge UP, 1982. 59-99.

. Discourse Strategies. Cambridge: Cambridge UP, 1982. Ch. 3: "Code-Switching for Pragmatic Motivations."

, and D. Hymes. Directions in Sociolinguistics: The Ethnography of Communication. Oxford: Basil Blackwell, 1986.

Heller, M., ed. Codeswitching: Anthropological and Sociolinguistic Perspectives. Berlin: Mouton/de Gruyter, 1988.

McClure, E., and M. McClure. "Macro- and Micro- Sociolinguistic Dimensions of Code-Switching in Vingard (Romania)." Codeswitching: Anthopological and Sociolinguistic Perspectives. Ed. Monica Heller. Berlin: Mouton/de Gruyter, 1988. 25-52.

Milroy, L. Language and Social Networks. Oxford: Basil Blackwell, 1980. - "Social Network and Language Maintenance." Language and Language Use: A Reader. Ed. A. K. Pugh, V. J. Lee and J. Swann. London: Heineman, 1980. 35-36. . "Social Network and Linguistic Focusing." Sociolinguistic Variation in Speech Communities. Ed. Suzanne Romaine. London: Edward Arnold, 1982. 141-52.

, and S. Margrain. "Vernacular Language Loyalty and Social Network." Language in Society 9.1 (1980): 43-70.

Montes Granado, C. Sons and Lovers y las tres versiones de Lady Chatterley's Lover: interpretación sociolingüística. Salamanca: Ediciones Universidad de Salamanca, 1993. Secs II.2 and II.3.

"Interpretación sociolingüística del idiolecto del guardabosques en Lady Chatterley's Lover." Actas del XIV Congreso de AEDEAN. Vitoria: Universidad del País Vasco, 1993. 267-73.

"Pérdida de la interacción entre la construcción textual y su referente sociolingüístico en la versión traducida." Intertextuality in British Writing. Alcalá de Henares: Publicaciones Universidad de Alcalá de Henares, forthcoming. The sociolinguistic referent being the code-switching behaviour of the gamekeeper in Lady Chatterley's Lover.

Parasher, S. N. "Mother-Tongue-English Diglossia: A Case Study of Educated Indian Bilinguals’ Language Use.” Anthropological Linguistics 22.4 (1980): 151-68. 
Poplack, S. “'Sometimes I Start a Sentence in English y termino en español': Toward a Typology of Code-Switching." Linguistics 18 (1980): 581-618.

- "Contrasting Patterns of Codeswitching in two Communities." Codeswitching:

Anthropological and Sociolinguistic Perspectives. Ed. Monica Heller. Berlin: Mouton/ de Gruyter, 1988. 215-44.

, and D. Sankoff. "Codeswitching." In Sociolinguistics/Soziolinguistik. Ed. Ulrich

Ammon, Norbert Dittmar and Klaus J. Mattheier. Berlin: Walter de Gruyter, 1988.

2: $1174-80$.

Pride, J. B. The Social Meaning of Language. London: Oxford UP, 1971. , and J. Holmes, eds. Sociolinguistics. Harmondsworth: Penguin, 1972.

Romaine, S. Bilingualism. Oxford: Basil Blackwell, 1989. Chs. 2 and 4. . Language in Society: An Introduction to Sociolinguistics. Oxford: Oxford UP, 1994. Ch. 2. 1982.

, ed. Sociolinguistic Variation in Speech Communities. London: Edward Arnold,

Sankoff, D., and S. Mainville. "Code-Switching of Context-Free Grammars.” Theoretical Linguistics 13 (1986): 75-90.

Sankoff, G. The Social Life of Language. Philadelphia: U of Pennsylvania P, 1980. "Language Use in Multilingual Societies: Some Alternate Approaches" 29-46.

Scotton, C. M. "Strategies of Neutrality: Language Choice in Uncertain Situations." Language 52 (1976): 919-41.

. "The Negation of Identities in Conversation: A Theory of Markedness and Code

Choice." International Journal of the Sociology of Language 44 (1983): 115-36.

. "Code-Switching as Indexical of Social Negotations." Codeswitching:

Anthropological and Sociolinguistic Perspectives. Ed. Monica Heller. Berlin: Mouton/ de Gruyter, 1988. 151-86.

. Motivations for Code-Switching: Evidence from Africa. Oxford: Oxford UP, 1988. , and W. Ury. "Bilingual Strategies: the Social Functions of Code-Switching."

International Journal of the Sociology of Language 13 (1975): 5-20.

Shuy, R. W., and R. W. Fasold, eds. Language Attitudes: Current Trends and Prospects. Washington: Georgetown UP, 1973.

Thakerar, J. N., H. Giles, and J. Cheshire. "Psychological and Linguistic Parameters of Speech Accommodation Theory." Advances in the Social Psychology of Language. Ed. Colin Fraser and Klaus R. Scherer. Cambridge: Cambridge UP, 1982. 205-49.

Wardhaugh, R. An Introduction to Sociolinguistics. Oxford: Basil Blackwell, 1986. Ch. 4. 